九州大学学術情報リポジトリ

Kyushu University Institutional Repository

\title{
Erosion in the Western Middle Mountain Watersheds of Nepal : A Review
}

\section{Paudel, Prem P.}

Joshi, Jaqannath

Laboratory of Forest Conservation, Division of Forest Environment and Management Sciences, Department of Forest and Forest Products, Graduate school of Bioresource and Bioenvironmental Sciences, Kyushu University

Omura, Hiroshi

Laboratory of Forest Conservation, Division of Forest Environment and Management Sciences, Department of Forest and Forest Products, Faculty of Agriculture, Kyushu University

https://doi.org/10.5109/24425

出版情報 : 九州大学大学院農学研究院紀要. 46 (1)，pp. 83-91，2001-10-30. Kyushu University バージョン：

権利関係 : 


\title{
Erosion in the Western Middle Mountain Watersheds of Nepal: A Review
}

\author{
Prem P. PAUDEL*, Jagannath JOSHI* and Hiroshi OMURA** \\ Laboratory of Forest Conservation, Division of Forest Environment and Management Sciences, \\ Department of Forest and Forest Products, Faculty of Agriculture, \\ Kyushu University, Fukuoka 812-8581, Japan \\ (Received June 29, 2001 and accepted July 11, 2001)
}

\begin{abstract}
Soil erosion and mass movement are the major causes of the middle mountain environmental degradation in Nepal. The middle mountain region comprises about $30 \%$ of the country area, which ranges between the elevations of $300 \mathrm{~m}$ to $3000 \mathrm{~m}$ above the sea level. The number of landslide distribution per 100 ha area in 5 different watersheds varies from 0.89 to 3.20 . The number of landslides by land use type per 100 ha is largest at grassland with 6.98 , followed by non-irrigated cultivated land with 1.90 and least at irrigated cultivated land with 0.85 . The shallow landslides are greater in number at above $30^{\circ}$ slope angle. The estimated soil loss from grassland and farmland is more than 170-180ton/ha/year. The onsite significance of surface erosion is reduction of the productivity. While its off-site significance is in causing siltation, water pollution etc. in the downstream areas.
\end{abstract}

Key words: Landslide, bank erosion, surface erosion, Nepalese middle mountain

\section{INTRODUCTION}

Nepal is a mountainous country, situated between the latitude of $26^{\circ} 22^{\prime}$ to $30^{\circ} 27^{\prime} \mathrm{N}$ and longitude of $80^{\circ} 04^{\prime}$ to $88^{\circ} 12^{\prime} \mathrm{E}$. The physical environment of Nepal is dominated by a major mountain--building process and situated in the central part of the great Himalayan arc, which extends for about $2400 \mathrm{~km}$ from the Punjab Himalaya located at India in the west to the north eastern frontier area or Assam Himalaya in the east. The middle strip of $820 \mathrm{~km}$ constitutes Nepal. The physiographic north-south cross section is similar throughout the Himalaya, therefore a simple geo-tectonic zonation is applicable for Nepal, too. As a result of northward movement of Indian plate, it has been drawn downwards and thrust below the Eurasian plate. The collision of these two plates creates problems of frequent occurrence of natural disasters along the Himalayan region. It is estimated that about $20 \%$ of Indian Himalayan region is in degraded conditions (Bahadur 1998).

Broadly the country is divided into five different physiographic regions namely: High Himal (elevation $4000 \mathrm{~m}-8848 \mathrm{~m}$ ), High Mountain ( $2300 \mathrm{~m}-4000 \mathrm{~m}$ ), Middle Mountain $(300 \mathrm{~m}-3000 \mathrm{~m})$, Siwalik $(300 \mathrm{~m}-1500 \mathrm{~m})$ and Terai $(70 \mathrm{~m}-300 \mathrm{~m})$ (LRMP 1986). The characteristics of each region vary significantly. In High Himal valley glaciers are

\footnotetext{
* Laboratory of Forest Conservation, Division of Forest Environment and Management Sciences, Department of Forest and Forest Products, Graduate school of Bioresource and Bioenvironmental Sciences, Kyushu University

** Corresponding author (Email: HYPERLINK "mailto:homura@agr.kyushu-u.ac.jp" homura@agr. kyushu-u.ac.jp)
} 
common, while on the densely populated middle hill large number of slope failure occur frequently. The Siwalik region is unstable due to fragile geology, and the Terai region has flat plain with flood and sedimentation problem. Thus mountain slopes rarely achieve a truly straight profile because of above mentioned different features as well as variations of rock type, structure and weathering environment. The history of Himalayan geo-morphology is one of a continuous succession during periods of rapid adjustment towards a more stable state i.e. slope angle have been reduced. In the present landscape of the middle mountains five different principle slope elements are identified and they are ridge top of $15^{\circ}-45^{\circ}$, upper slope of $15^{\circ}-25^{\circ}$, mid slope of $20^{\circ}-30^{\circ}$, lower slope of $30^{\circ}-45^{\circ}$, and river valley of $0^{\circ}-15^{\circ}$ (Howell 1999). The schematic cross section of a typical mountain valley slope of the middle mountain is shown in Figure 1.

Due to the geological conditions as well as different geomorphological characteristics, the mid mountain watersheds are under the conditions of increasing state of surface erosion and mass wasting. In the midlands of Nepal, shallow landslides are common due to cultivation, deforestation and cutting at outer side of river wherever it turns a course. In the eastern part of middle mountains, phylites, shales and schists showed no significant difference in the degree or type of mass wasting. Major factors contributing to the natural instability and resulting mass movements in the middle mountains are: structure and inclination of slope; number and density of natural fracture planes; type of rock or mineral, state of weathering, and the presence of water (Shiwakoti 2000).

To study the state of erosion from the middle hill region of western Nepal, the five watersheds from two districts i.e. from Kaski and Parbat districts were studied in 1994 (Figure 2) jointly by the multidisciplinary team of Japan International Co-operation Agency (JICA) and His Majesty's Government of Nepal (HMG/N). This review paper analyze and presents some important information regarding soil erosion in Nepalese

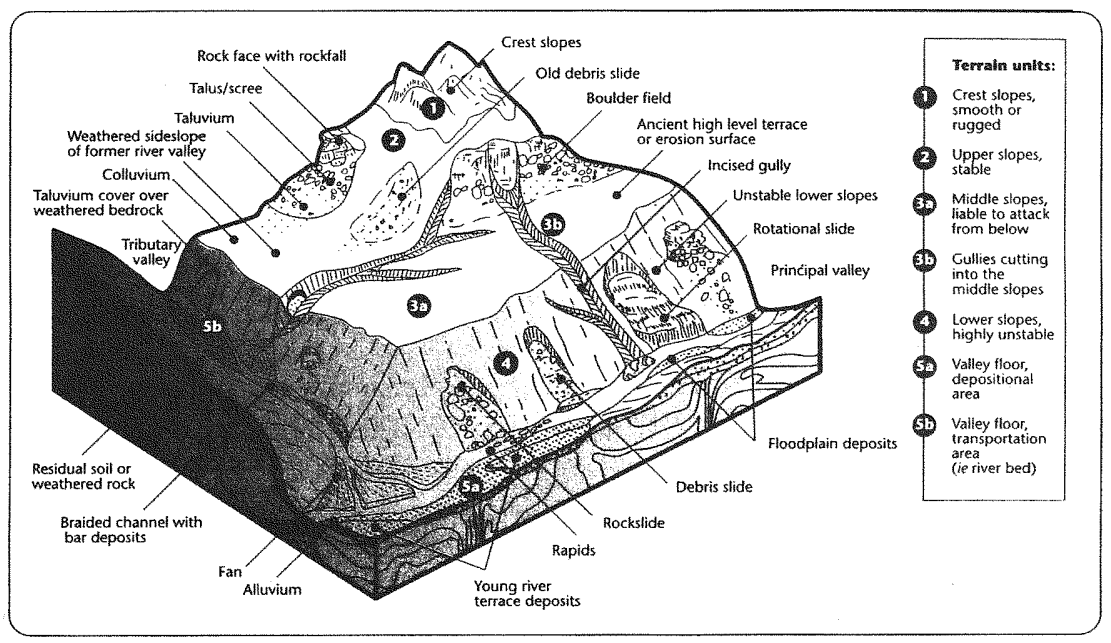

Fig. 1. Schematic cross-section of a typical mountain valley slope in the middle mountain (After Fookes et al; 1985 and Transport Research Laboratory 1997). 


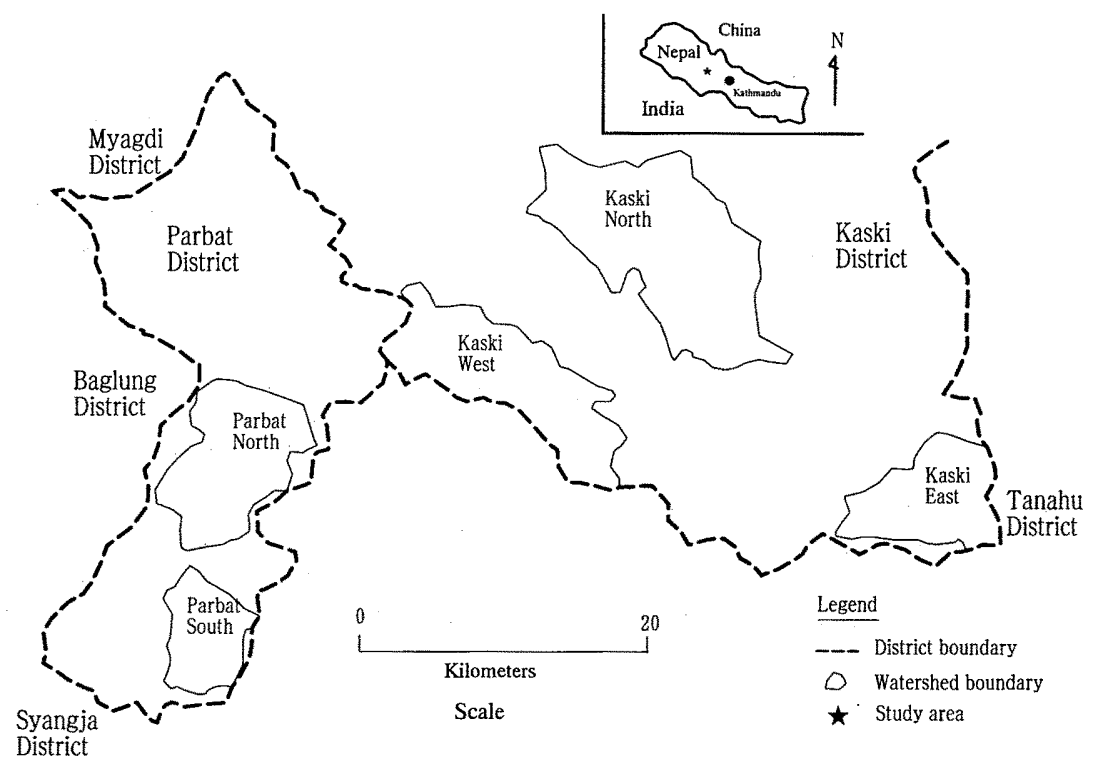

Fig. 2. Location map of the study area.

Middle Mountain watersheds through incorporating information obtained from such an inventory.

\section{NATURAL CONDITIONS OF WATERSHEDS}

The climate of the watersheds is subtropical to warm temperate. The annual precipitation at Parbat North watershed during monsoon season is up to $2518 \mathrm{~mm}$ (Lumle agriculture center rainfall station) and about $5377 \mathrm{~mm}$ at Kaski North watershed (Near Pokhara airport rainfall station). About $85 \%$ of the total annual precipitation falls only in the monsoon season that lasts from June to September.

Large rivers in the watersheds are Seti and Madi. Both rivers originate from the Annapurna range in the Himalayas and flow north-south and finally join each other into Narayani river. All other streams around the watersheds like Kalikhola, and Lamaya khola are the tributaries of these two rivers. The stream discharge of Seti river during dry and monsoon season is $2.1 \mathrm{~m}^{3} / \mathrm{sec}$ and $383.8 \mathrm{~m}^{3} / \mathrm{sec}$ respectively. Similarly that of Madi river is $2.8 \mathrm{~m}^{3} / \mathrm{sec}$ and $523.0 \mathrm{~m}^{3} / \mathrm{sec}$ (HMG/JICA 1998a).

These watersheds belong to the lower Himalayan zone (Matsuura 1997). The inner lesser Himalayas are characterized by a mature topography and extensive development of soil originated from slate, phyllite and schist. Sedimentary rocks like sandstone and shale are more common in the southern part while metamorphic rocks like phyllite and crystalline schist are common in the northern part of the watersheds area. A major thrust named as main central thrust, accompanied with Phalebas thrust runs in the watersheds 
area with strikes in the WNW-ESE direction (Matsuura 1997). Besides these thrust a large number of small to medium fault exists causing intensive deformation, and fracturing rocks. The soil texture distribution around watersheds are of sandy loam, clay loam and sand. The total area of the watersheds is about $41143 \mathrm{ha}$, of which about $46 \%$ is occupied by forest land, $28 \%$ by non--irrigated Bari land, $11 \%$ by irrigated Khet land, $6 \%$ by grassland and $9 \%$ by others. The vegetation is dominated by tropical mixed hardwood species and also found deciduous mixed broad- leaved species together with pine and alder.

\section{EROSION}

The landslides occurred in the watersheds are classified as shallow type and deep seated one. The former one has a scale within a depth of $1.0 \mathrm{~m}$ to $3.0 \mathrm{~m}$ and affected area size is $100-3000 \mathrm{~m}^{2}$. The latter is deeper than $3.0 \mathrm{~m}$ and of more than $3000 \mathrm{~m}^{2}$. Landslides in each watershed is listed in Table 1 . Concerning about the density per 100 ha by land use type is the largest at grassland with 6.98 , followed by Bari land with 1.90 , shrub with 1.63 ,

Table 1. Density of landslides in different watersheds.

\begin{tabular}{lrcccc}
\hline Location & $\begin{array}{c}\text { Area } \\
\text { (ha.) }\end{array}$ & $\begin{array}{c}\text { Shallow landslide } \\
\text { (Number) }\end{array}$ & $\begin{array}{c}\text { Deep seated landslide } \\
\text { (Number) }\end{array}$ & $\begin{array}{c}\text { Total } \\
(-)\end{array}$ & $\begin{array}{c}\text { Density } \\
\text { (No./100ha) }\end{array}$ \\
\hline Kaski North & 14068 & 235 & 58 & 293 & 2.08 \\
Kaski East & 5471 & 35 & 14 & 49 & 0.89 \\
Kaski West & 9886 & 87 & 25 & 112 & 1.13 \\
Parbat North & 7877 & 79 & 38 & 117 & 1.48 \\
Parbat South & 3841 & 101 & 23 & 124 & 3.199 \\
\hline Total & 41143 & 537 & 158 & 695 & 1.68 \\
\hline
\end{tabular}

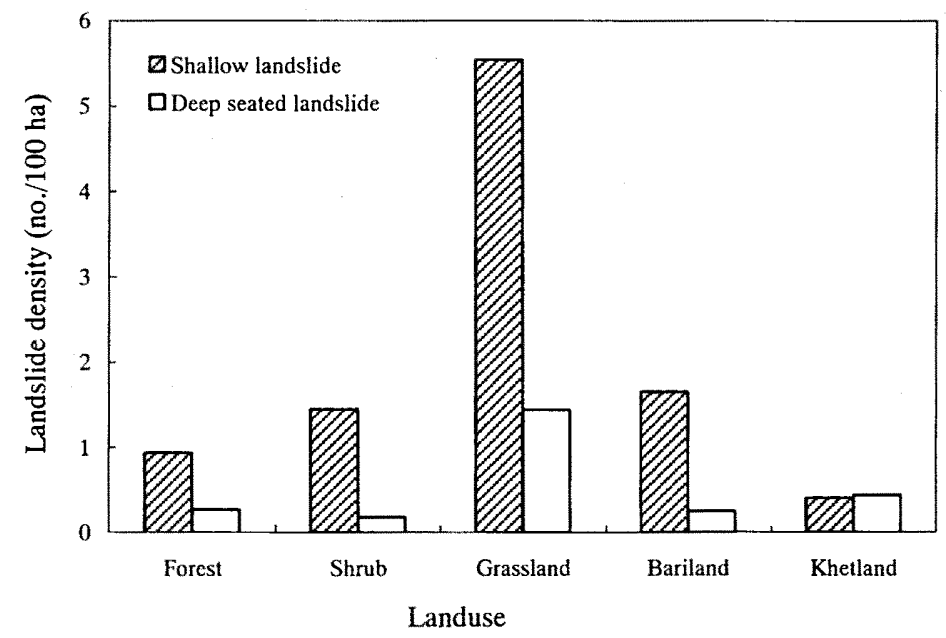

Fig. 3. Density of landslides by landuse type. 
forest with 1.20 and Khet land with 0.85 (Figure 3). In terms of slope, the density is greatest at more than $30^{\circ}$ slope category (Figure 4 ). One of the probable reason for higher number of landslide density in grassland is due to thick soil cover, low vegetation coverage and shallow rooting system. The density of landslide in Parbat south watershed is highest among others. This might be due to deeply weathered bed rocks eroded by undercutting effect of Argaudi stream. An example of a deep seated landslide is shown in Photo 1.

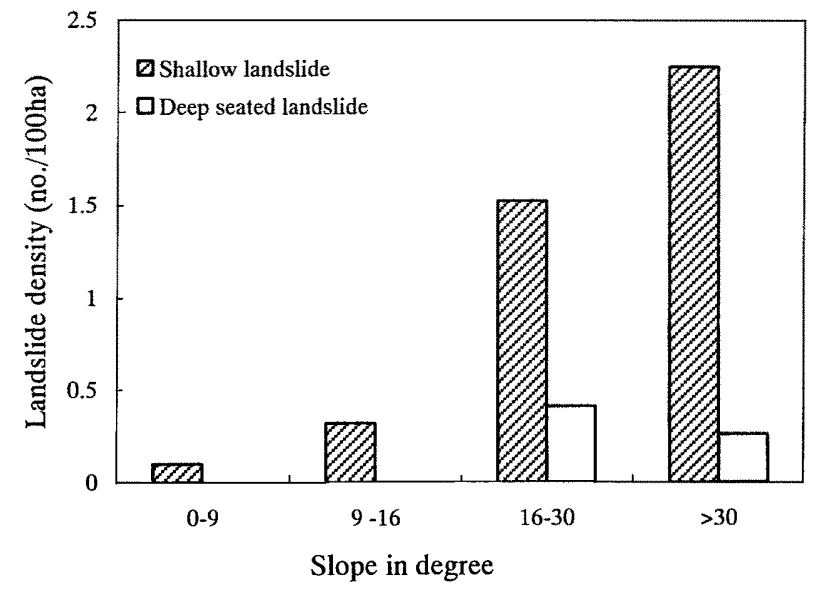

Fig. 4. Density of landslides by slope category.

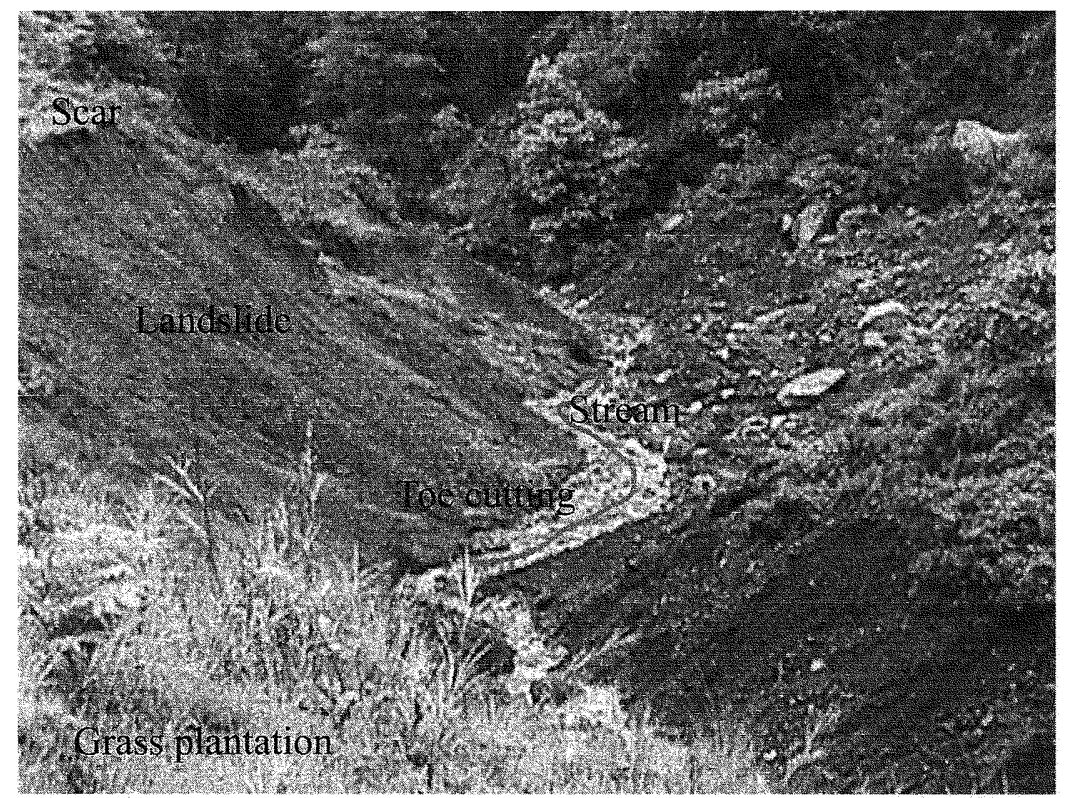

Photo. 1. Toe cutting of a deep seated landslide and side erosion by a stream in Parbat North watershed. 
The gully erosion has occurred mainly due to an increase of surface run-off because of over-grazing, improper farmland management, construction of trails and rural roads without side drainage. It looks more serious in cultivated land. There are so many gullies in the watersheds most prominent areas are in Kaski North and Parbat south area. The conditions of gullies are presented in Table 2, where the shape of gullies depends on soil properties and direction of flow of water in the ground. The U shape gully is formed if the resistance of the subsoil against erosion is equals with that of the top soil. On the contrary $\mathrm{V}$ shape gully is formed if the subsoil is more resistive than the top soil (HMG/JICA 1998a). The view of gully formation in filled bank slope is shown in Photo 2.

Each watershed in the study area is not an unit watershed discharging surface stream flow through only one outlet but also has, relatively small sub-watersheds. During high flows in the monsoon season, generally there are problems of bank erosion and over flowing related with flood. The upper layer of most banks has soils overlaying a loose sediment layer composed of sand and gravel, which is easily eroded and washed away

Table 2. Gullies in Kaski North and Parbat South.

\begin{tabular}{lccccccc}
\hline \multirow{2}{*}{ Location } & \multirow{2}{*}{ Length (m) } & \multicolumn{2}{c}{ Depth $(\mathrm{m})$} & \multicolumn{2}{c}{ Width $(\mathrm{m})$} & \multirow{2}{*}{ Gradient $\left(^{\circ}\right)$} & \multirow{2}{*}{ Type } \\
& & max. & min. & max. & min. & & \\
\hline \multirow{2}{*}{ Kaski North } & 36 & 6.0 & 4.5 & 10.0 & 6.5 & 26 & U shape \\
& 200 & 3.4 & 2.9 & 10.0 & 6.5 & 6.5 & U shape \\
& 105 & 6.5 & 3.7 & 21.0 & 13.5 & 7 & V shape \\
\multirow{2}{*}{ Parbat South } & 150 & 2.2 & 2.0 & 13.5 & 12.0 & 15 & V shape \\
\hline
\end{tabular}

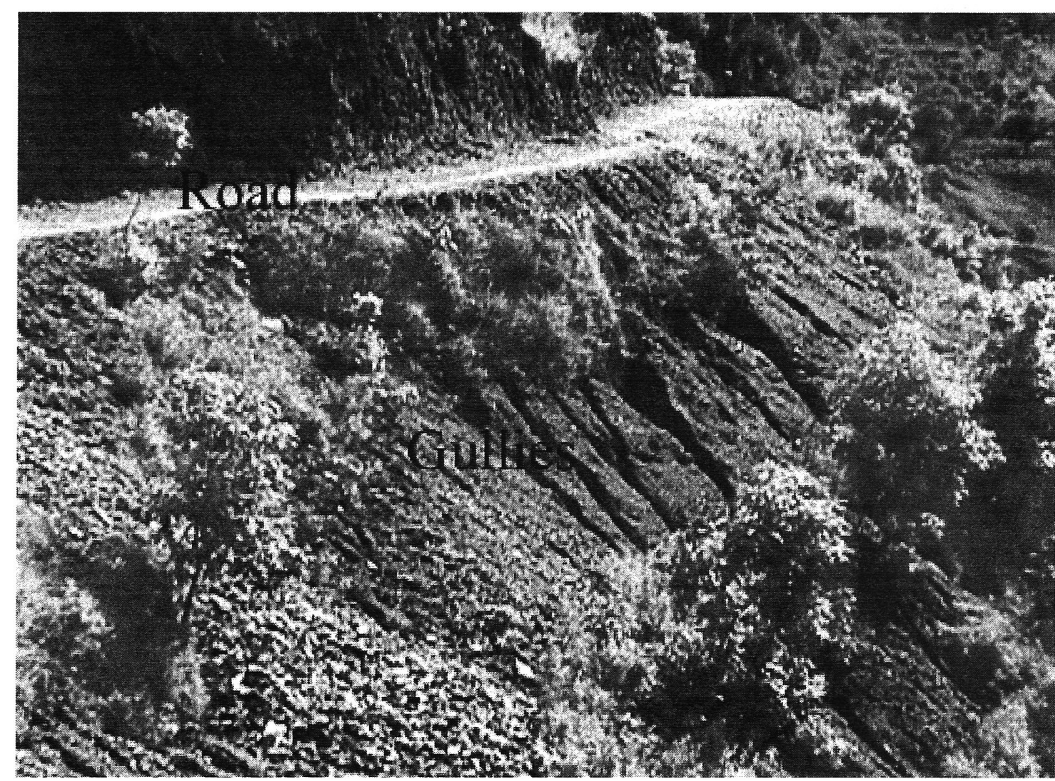

Photo. 2. V shape gully formation on filled bank slope formation below the road. 
mainly during monsoon season. The bank erosion on both sides of the streams of each watershed is shown in Figure 5. The erosion in Kaski North watershed is highest. It might be due to activities of major tributaries like Bijayapur stream, Kali stream, and Bhoti streams. A typical example of bank erosion is shown in Photo 3.

A sustainable use of land without progressive deterioration can be achieved when the

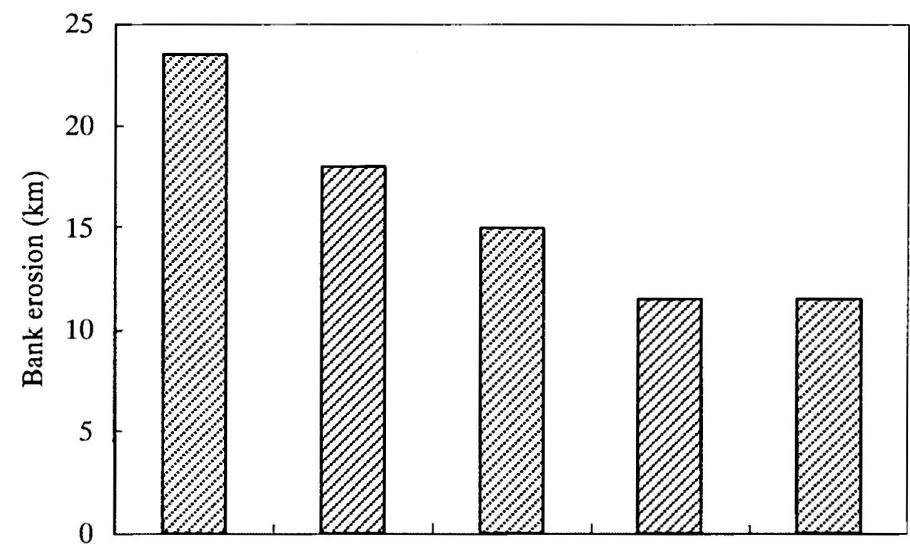

Kaski North Kaski East Kaski West Parbat North Parbat South

Watersheds

Fig. 5. Condition of bank erosion at both sides of streams.

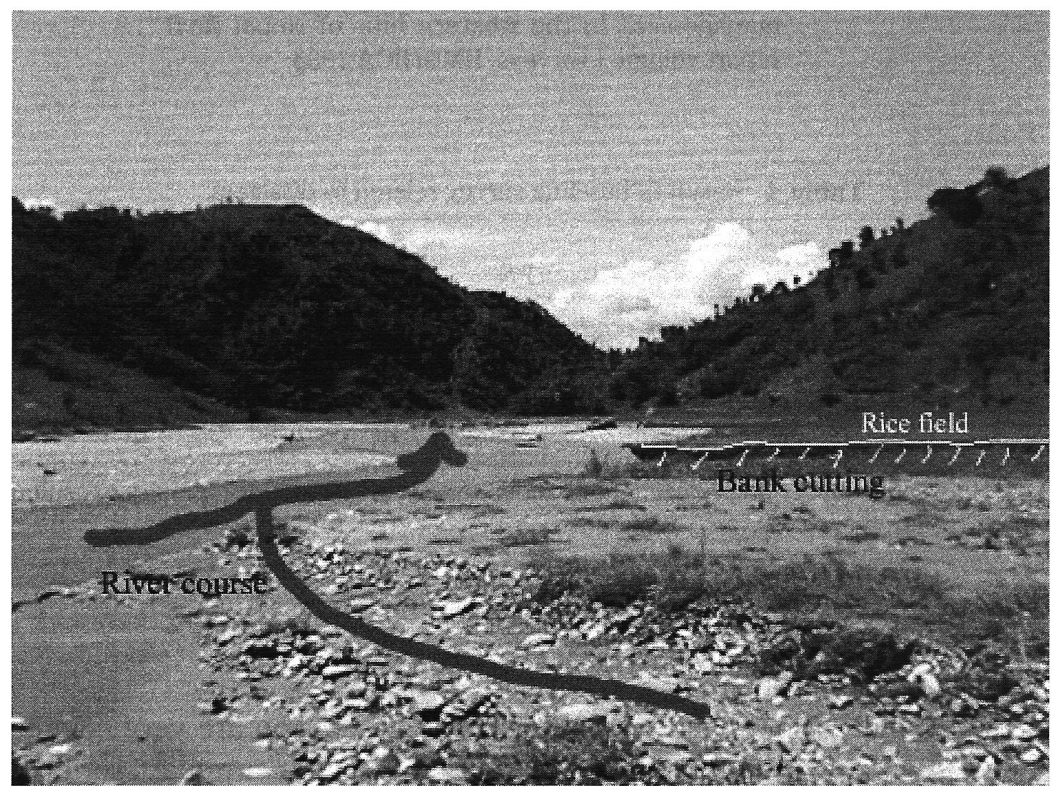

Photo. 3. View of Bank cutting by Bijayapur stream in Kaski North Watershed area. 
rate of soil loss is no greater than the rate of soil formation. However it can not be precisely measured, but when the disturbances, aeration and leaching actions are accelerated by tilling the land, it will take some 100 years to form $25 \mathrm{~mm}$ of soil (HMG/JICA 1998a). According to Nepal Agriculture Research Council, bulk density of soils in the middle mountains of Nepal vary from 1.0 to $1.4 \mathrm{gm} / \mathrm{cm}^{3}$. Assuming the bulk density of $1.2 \mathrm{gm} / \mathrm{cm}^{3}$, soil formation is approximately $3.0-10.0$ ton/ha/year (HMG/JICA 1998a). The rate of soil loss by surface erosion in different land use type is classified in Table 3. Severe surface erosion occurs in overgrazed grassland due to surface run-off caused by poor vegetation as a result of overgrazing, where surface run-off is as much as $53 \%$ of the total annual precipitation (HMG/JICA 1998a). The average population of cow and goat per household in Parbat North (PN), Parbat South (PS), Kaski East (KE), Kaski North (KN), and Kaski West (KW) is 2.4, 2.8, 4.0, 2.5, and 2.6, respectively so that the grazing pressure to the top soil seems to be high.

Further, the people living in the watersheds area are frequently affected by soil erosion. To find out the condition of disaster there, the household survey was conducted in 1996. Result of problem related to disaster in watersheds mentioned above is cited in Table 4.

Table 3. Soil loss from surface erosion by landuse type.

\begin{tabular}{lc}
\hline Land use type & Soil loss (ton/ha/year) \\
\hline Slopping terrace & $60-70$ \\
Home garden & 3 \\
Overgrazed grassland & 110 \\
\hline Source: The development study on Integrated watershed \\
management in the western hills of Nepal final \\
report volume I surveys, HMG/JICA 1998.
\end{tabular}

Table 4. Result of baseline survey related to disasters.

\begin{tabular}{llccccc}
\hline \multirow{2}{*}{ Disaster } & Items & \multicolumn{4}{c}{ Watershed area } \\
\hline Landslide & $\begin{array}{l}\text { Frequently affected } \\
\text { household (\%) }\end{array}$ & 33 & 31 & 9 & 12 & 12 \\
Flood & $\begin{array}{l}\text { Frequently affected } \\
\text { household (\%) }\end{array}$ & 10 & 10 & 30 & 14 & 12 \\
\hline
\end{tabular}

Source: Household survey and household member survey, JiCA/multidisciplinary consultants 1996.

\section{CONCLUSION}

Landslides, gully erosion, bank erosion and surface erosion are very common in the middle mountain watersheds of Nepal where natural disasters are most serious problem to conservation of resources (Joshi et al; 1998) and also damage to infrastructure, 
farmland and lives \& property of local people. Therefore nation takes the attention.

Gully erosion was found mostly in bare slopes, and it has triggered landslides through undercutting the foot of a slope. The possible causes of landslides may be due to geological factors inherent to the mountains such as fractured, deeply weathered rock, which allows water penetration. Similarly the diversified geomorphological features of the mountain slopes are equally responsible. Further human activities such as degradation of forest and grassland by over exploitation, improper farmland management, construction of trail, canals for irrigation and roads without any proper drainage. The landslides in grassland were highest due to presence of thick soil layer, poor vegetation coverage besides having weakened geological settings.

Considering the above erosion state in the middle mountain region some integrated management programs are essential to mitigate the problems. Such as conservation of forest resources, mitigation of landslide, flood management and soil conservation, increase of fuel-wood, fodder and timber production, improving the living conditions of villagers through increasing food production, protection of downstream area while constructing some infrastructure in the upstream side, protection and improvement of existing water source areas are some activities to reduce the existing problems.

Thus detail studies on mechanism, cause and preventive measures on landslide, surface erosion and bank erosion are essential in the middle hills of Nepal in order to mitigate the problems.

\section{REFERENCES}

Bahadur, J. 1998 Water resources management in the Himalayan region. http://www.mtnforum. org/resources/library/bahaj98a.htm

HMG/JICA 1998a The development study on integrated watershed management in the western hills of Nepal. Final report, Volume I, Surveys, Japan Forest Technical Association, Kokusaikogyo Co. Ltd. pp. 43-136

HMG/JICA 1998b The development study on integrated watershed management in the western hills of Nepal, socio-economic base line survey. Main report. Japan Forest Technical Association, Kokusaikogyo Co. Ltd. pp.

HMG/JICA 1998c The development study on integrated watershed management in the western hills of Nepal. Final report. Volume II, Japan Forest Technical Association, Kokusaikogyo Co. Ltd. pp.

Joshi, J., T. N. Bhattarai, K. M. Sthapit and H. Omura, 1998 Soil Erosion and Sediment Disaster in NepalA Review. Journal of Faculty of Agriculture, Kyushu University, 42: 491-502

Howell, J. 1999 Reference manual on roadside bioengineering. Department of Roads, His Majesty's Government of Nepal. pp. 41-61

LRMP 1986 Summary report. Land Resource Mapping Project. Nepal

Shiwakoti D. R. 2000 An assessment of soil loss and natural hazards in Nepal. Journal of Nepal Geological Society, Vol. 21, pp. 41-48

Matsuura, S. 1997 The condition of mass-wasting and erosion in the area of community development and forest/watershed conservation project in western Nepal. Forestry and Forest Products Research Institute, Forestry Agency, Report on Forestry Research Overseas. pp. 93-100 